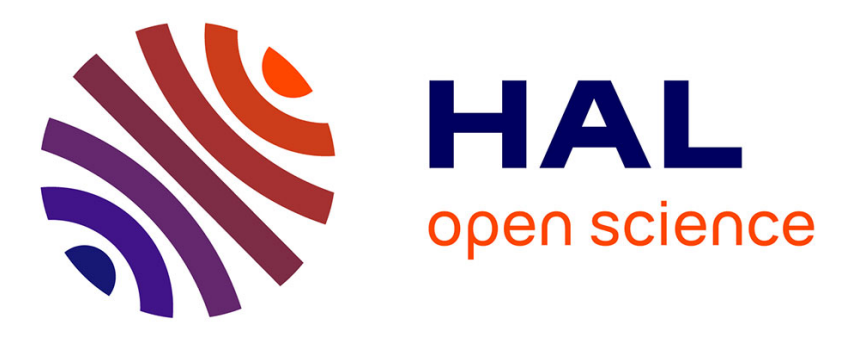

\title{
Integrating corporate social responsibility into conservation policy. The example of business commitments to contribute to the French National Biodiversity Strategy \\ Anastasia Wolff, Natacha Gondran, Christian Brodhag
}

\section{To cite this version:}

Anastasia Wolff, Natacha Gondran, Christian Brodhag. Integrating corporate social responsibility into conservation policy. The example of business commitments to contribute to the French National Biodiversity Strategy. Environmental Science and Policy, 2018, 86, pp.106 - 114. 10.1016/j.envsci.2018.05.007 . emse-01794248

\section{HAL Id: emse-01794248 \\ https://hal-emse.ccsd.cnrs.fr/emse-01794248}

Submitted on 17 May 2018

HAL is a multi-disciplinary open access archive for the deposit and dissemination of scientific research documents, whether they are published or not. The documents may come from teaching and research institutions in France or abroad, or from public or private research centers.
L'archive ouverte pluridisciplinaire HAL, est destinée au dépôt et à la diffusion de documents scientifiques de niveau recherche, publiés ou non, émanant des établissements d'enseignement et de recherche français ou étrangers, des laboratoires publics ou privés. 
Title: Integrating corporate social responsibility into conservation policy. The example of business commitments to contribute to the French National Biodiversity Strategy

Authors: Anastasia Wolff ${ }^{(a, b)}$, Natacha Gondran ${ }^{(b)}$, Christian Brodhag ${ }^{(b)}$

Affiliations:

(a) AgroParisTech, F-75005, Paris, France

(b) Mines Saint-Etienne, Univ Lyon, Univ Jean Moulin, Univ Lumière, Univ Jean Monnet, ENTPE, INSA

Lyon, ENS Lyon, CNRS, UMR 5600 EVS, Institut Henri Fayol, F - 42023 Saint-Etienne France

Corresponding author:

Anastasia Wolff, anastasia.wolff@ developpement-durable.gouv.fr

Ministère de la transition écologique et solidaire, Tour Sequoia

92055 La Défense cedex, France

\section{Summary}

Corporate social responsibility (CSR) is receiving an increased attention in biodiversity policy. This exploratory study analyses biodiversity-oriented corporate practices and stakeholders' involvement in their implementation based on a content analysis of 34 business commitment plans endorsed as contributions to the French National Biodiversity Strategy and Action Plan (NBSAP). A trans-sectoral typology of practices emerged from this analysis. This typology categorizes, on one hand, CSR practices that directly mitigate biodiversity loss, and on the other hand, procedural activities supporting a better integration of biodiversity issues. External stakeholders were found to be involved in more than two thirds of the CSR actions and played different roles depending if they belonged to the territorial system, the value chain or the institutional system the company. The article concludes with a number of implications for policy-makers as well as business managers and opens research avenues.

Key words: conservation policy; corporate social responsibility; business practices; mitigation hierarchy; stakeholders; NBSAP 


\section{Introduction}

Halting biodiversity erosion is a tremendous challenge, as human-induced biodiversity loss has reached exceptionally high rates (Ceballos et al., 2017). It has been argued that the governance of biodiversity cannot rely solely on a law-based approach, but that a multiplicity of other sources of normative rules, integrating the potential role of all groups with relevant interests, are necessary to design an effective policy portfolio (Doremus, 2003; Sampford, 2002). Given the role companies play in biodiversity alteration and their financial and political power, expectations regarding business contribution to biodiversity conservation are growing (Robinson, 2012). In 2010, the Conference of the Parties (COP) of the Convention for biological diversity (CBD), the main international governance body for biodiversity conservation, adopted a Decision entitled "Business engagement" that "[recognizes] the importance of drawing on the capacities of business and private enterprise" and invited the parties "to promote a public policy environment that enables private sector engagement and the mainstreaming of biodiversity into corporate strategies and decision-making" (COP10 CBD, 2010). Such an engagement of companies in biodiversity conservation can be considered as part of their corporate social responsibility (CSR), as CSR "concerns actions by companies over and above their legal obligations towards society and the environment" (European Commission, 2011). Mobilizing CSR in conservation policy thus rely on non-coercive, voluntary approaches (Börkey et al., 2000).

While biodiversity issues had been poorly integrated in CSR compared to other environmental challenges (Ernst and Honoré-Rougé, 2012), this political momentum seems to have participated to bring biodiversity issues to economic actors' attention. In a survey comprising more than 1,500 business executives, $64 \%$ answered that biodiversity was important to some level to their companies (Bonini and Oppenheim, 2010). Disclosure on biodiversity issues in CSR reporting has also significantly increased these last years (Adler et al., 2017). A multiplicity of international standard-settings and monitoring mechanisms have been developed in line with the framework provided by the CBD (Morgera, 2012), along with new assessment tools (Wolff et al., 2017a). While this gain of visibility may have led firms to put biodiversity higher on their political agenda, whether this translates into concrete efforts to reduce biodiversity loss still needs to be investigated. This materialization is not obvious as the implementation of practical measures has been found to be challenging for companies (Overbeek et al., 2013; Robinson, 2012). Criticisms have raised regarding the effectiveness and the legitimacy of mobilizing the private sector (MacDonald, 2010; Robinson, 2012; Rose and Colchester, 2004). Understanding what are (or could be) the effective conservation impacts of biodiversity-oriented CSR has thus become critical for conservationists and policy makers (Sutherland et al., 2009): What kind of concrete practices do companies put in place as part of their CSR? Who is involved in their implementation? How to integrate CSR in the policy portfolio so that it effectively contributes to the achievement of conservation objectives?

Biodiversity-oriented CSR approaches have been somewhat overlooked in the scientific literature. A few studies looked more closely at the corporate practices of specific sectors, such as farming (de Snoo et al., 2013; Santangeli et al., 2016), fish processing (Wolff and Schmitt, 2009), forestry and mining (Boiral and Heras-Saizarbitoria, 2017a) but this literature is still fragmented. There is thus a need to undertake a trans-sectoral review of business initiatives and to develop a comprehensive framework to classify and interpret them in a consistent manner (Winn and Pogutz, 2013). Several studies have pointed out that stakeholders involvement was 
crucial in the implementation of corporate practices related to biodiversity conservation, notably because of their complexity and the need for business to comfort the legitimacy of such measures (Boiral and Heras-Saizarbitoria, 2017b; Overbeek and Harms, 2011; Reade et al., 2014). The collective nature of biodiversity-oriented CSR practices thus seems to be an important parameter to take into account if contribution of businesses to biodiversity conservation is to be fostered.

The French National Biodiversity Strategy and Action Plan (NBSAP) 2011-2020 includes a public voluntary program (Börkey et al., 2000). This policy instrument is used to officially endorse commitment plans of organizations that contribute to the achievement of biodiversity conservation objectives. These commitment plans provide a quite detailed description of the actions that companies have put in place or plan to undertake. Building on the case study of the NBSAP corporate commitment plans, the objectives of this article are to propose a classification of biodiversity-oriented CSR practices, to provide some insights regarding the roles played by stakeholders in their implementation and based on this analysis to draw some lessons on how to better integrate CSR in the policy portfolio for biodiversity conservation.

The paper is organized as follows. Section 2 provides a literature review on biodiversityoriented CSR. Then, Section 3 describes the case study and the methodology used to analyze the corporate commitment plans. The results are subsequently presented in Section 4 in line with the research questions. Finally, Section 5 discusses the study's implications for policy makers and business managers as well as avenues for future research.

\section{Biodiversity-oriented CSR}

\subsection{Positioning CSR in the policy portfolio for biodiversity conservation}

There is a spectrum of policy options to engage businesses in biodiversity conservation: coercive approaches based on 'command and control' regulation (e.g. fishing quotas), marketbased mechanisms (e.g. payment for ecosystem services and certification schemes) (Lambooy and Levashova, 2011; Pirard, 2012) and voluntary approaches (with or without financial compensation) (Santangeli et al., 2016). Voluntary approaches are schemes whereby firms make commitments to improve their environmental performance (Börkey et al., 2000). Thus, CSR relates primarily to voluntary approaches, although market-based options can also be framed to fit within CSR definition. Three main types of voluntary approaches can be distinguished: unilateral commitments made by companies, environmental negotiated agreements between industry and public authorities and public voluntary programs (Börkey et al., 2000). The French NBSAP instrument on which is based this article is an example of public voluntary program for biodiversity conservation. Public authorities may develop other more indirect technics to influence CSR (Steurer, 2010).

Compared to regulatory and market-based mechanisms, the rationalities that shape the adoption of CSR practices are less explicit, and so are the political levers. Three forces may contribute to institutionalize CSR practices (DiMaggio and Powell, 1983; King and Lenox, 2000):

- coercive forces relate to the pressures institutional stakeholders can exert even in the absence of explicit penalties. Companies failing to respond to such external pressures are exposed to potential impacts on their political influence and legitimacy. Drivers of business engagement in ecological issues thus typically encompass improved regulatory 
compliance, social license to operate, reduced risk of conflict as well as access to capital (a growing number of investors and financing agencies impose ecological standards, such as the International Finance Corporation performance standard on biodiversity conservation and sustainable management of living natural resources (IFC, 2012)) (Barkemeyer et al., 2015).

- normative forces relate to the professionalization of firms notably through the development of sectoral standards. Certification systems and norms, whether they are public (the European organic certification) or private (e.g. the Forest Stewardship Council (FSC), the Global reporting initiative (GRI)) contribute to make more operational and concrete the issues of biodiversity for the company, acting as vectors of appropriation of these issues.

- mimetic forces contribute to the development of environmental CSR through the dissemination of information on best practices, private benefits and competitors' performances.

Thus CSR is not a policy tool for biodiversity conservation by itself but rather a corporate contribution that can be influenced and fostered by a spectrum of policy instruments.

\subsection{Business-biodiversity interactions and CSR practices}

Business engagement in biodiversity conservation can encompass a large variety of practices (CBD, online; Schaltegger and Beständig, 2012). How corporate activities interact with biodiversity and ecosystem services orientates the strategy and types of measures that may be adopted by a company (Houdet et al., 2012). Three types of business-biodiversity interplay can be distinguished (Feger, 2016; Overbeek et al., 2013):

1. business activities negatively affect biodiversity. Five types of anthropic pressures are responsible for biodiversity loss: habitat change, overexploitation of wild populations, invasive species, pollutions and climate change (Millennium Ecosystem Assessment, 2005; SCBD, 2010). Companies may exert such ecological pressures not only on their own industrial sites, but also beyond their land and premises, at multiple stages of their value chain through their operations, supply chains and the products and services they deliver (Wolff et al., 2017b).

2. business activities are dependent on services provided by ecosystems, such as natural water purification (e.g. water industry), soil erosion regulation (e.g. agriculture), material and food provision (e.g. forestry and fishery), aesthetic quality (e.g. tourism).

3. business activities contribute to strengthen biodiversity resilience through the provision of services to ecosystems (ecological engineering, depollution activities...).

In the first case, companies are expected to mitigate their impacts on biodiversity. Stakeholders, and notably NGOs, may pressure companies to go beyond regulatory compliance if they consider that ecosystems are threatened by corporate activities. Stakeholders can then either take an adversarial approach (i.e. expert coercive forces such as shame campaigns) or a cooperative approach by offering technical support to the firm or reward for compliance (Lyon and Maxwell, 2008). In the second case, a company has a direct incentive (its economic viability) to secure the quality and quantity of ecosystem services on which it relies by ensuring the maintenance of ecosystems' functioning (TEEB, 2012). Finally, companies whose core activities aim at improving ecosystems health may seek to develop innovative services and 
business models to support clients liable for ecosystem management (e.g. municipalities, private landowners) (Feger, 2016).

\subsection{The implementation of CSR practices in action arenas}

From an organizational point of view, corporate biodiversity practices can be classified based on who is in charge of, or involved in, their implementation. Boiral and Heras-Saizarbitoria proposed a framework that differentiates corporate biodiversity practices based on two main axes (Boiral and Heras-Saizarbitoria, 2017a):

- practices that are under the responsibility of managers (e.g. implementation of management systems) vs. under the responsibility of experts and specialists (e.g. fauna and flora inventories);

- internal practices that are implemented by the firm itself (e.g. monitoring of performance indicators) vs. external practices implemented in association with various stakeholders (e.g. research programs in partnership with academic institutions).

Such an involvement of external stakeholders in the implementation of corporate biodiversity can be understood both because of the collective nature of biodiversity issues (what Elinor Ostrom calls the "Commons") and because of CSR norms (ISO, 2010; OECD, 2011) that require companies not only to imbed CSR within their organizations but also to practice it throughout their spheres of influence, defined as the "rangelextent of political, contractual, economic or other relationships through which an organization has the ability to affect the decisions or activities of individuals or organization" (ISO, 2010, p. 4).

Corporate biodiversity practices can thus be implemented in different 'action arenas' (Ostrom, 2010) in which stakeholders are associated at different degrees from simple informative up to decisional positions (Green and Hunton-Clarke, 2003). The most frequently cited stakeholder categories in the ecological management literature are environmental NGOs, experts and academics, public authorities and industry coalitions (Barkemeyer et al., 2015; Boiral and Heras-Saizarbitoria, 2017b; Overbeek et al., 2013). The concept of action arena is used in this study to identify patterns of stakeholders' involvement in the implementation of biodiversityoriented CSR practices.

\section{Research design}

\subsection{The French National Biodiversity Strategy and Action Plan}

In order to translate the international conservation framework of the CBD at the national level, France updated its National Biodiversity Strategy and Action Plan (NBSAP) in 2011 with the ambition to "preserve, restore, strengthen and value biodiversity and ensure its fair and sustainable use; to involve everyone and every sector of activity, in order to succeed" (Prime Minister, 2011). This NBSAP includes an original instrument whose objective is to broaden actors' contribution. Organizations (companies, but also associations, local councils and public agencies) can engage on a voluntary basis in two steps: adherence to NBSAP principles and commitment to contribute to the NBSAP concretized by a commitment plan.

This instrument gives a large flexibility to project leaders to define the strategy and actions that will be part of their commitment plans. Commitment plans are evaluated based on a framework setting quality criteria (Box 1) through a peer-review process involving colleges representing 
different categories of stakeholders (state, local elected representatives, professional associations, workers unions, NGOs, public agencies as well as qualified individuals). Commitments that pass the review process are recognized as contributions to the French NBSAP for a three-year period (exceptionally for one-year only). The organization is then allowed to advertise the actions undertaken as contributions to the NBSAP.

Box 1-Criteria used by the NBSAP committee to evaluate the commitment plans.

- consistency with NBSAP targets

- consistency of the action plan (projects organization and phasing)

- level of involvement of the top management and stakeholders

- connection with core business activities and feasibility,

- significance of the ecological potential and scalability

- additionality relatively to regulatory obligations

- measurability

- adaptive management

- continual improvement perspective

- commensurability with the capacities of the organization

\subsection{Business commitment plans collection}

Between 2012 and 2016, 49 commitment plans submitted by private and public companies were recognized as contributing to the NBSAP (Ministère de la transition écologique et solidaire, 2017).Erreur ! Source du renvoi introuvable. "Energy", "mining and carrying", as well as "water, waste and environment" sectors are the most represented sectors in the program and large companies dominate (Figure 1).

All private and public companies whose commitment plans were endorsed between 2012 and 2016 were contacted by email to get an access to their commitment plans. 31 companies $(70 \%)$ responded positively. Although most commitment plans have a confidential status, a few are in open-access (Eiffage, 2015; GRTgaz, 2013; STB Matériaux, 2013; TIGF, 2013; Vertdéco, 2013). Figure 1 describes the composition of the studied sample compared to the profile of total business participants. It can be noticed that large companies are slightly under-represented compared to small and medium-size (SME) and intermediate-size enterprises, and that less than $50 \%$ of the actors from the waste-water-environment and finance sectors were included in the study. 
Figure 1-Companies characteristics. Black marks indicates the number of companies included in the study relatively to the number of companies with NBSAP commitments (grey bars) by (a) sectors and (b) business size.

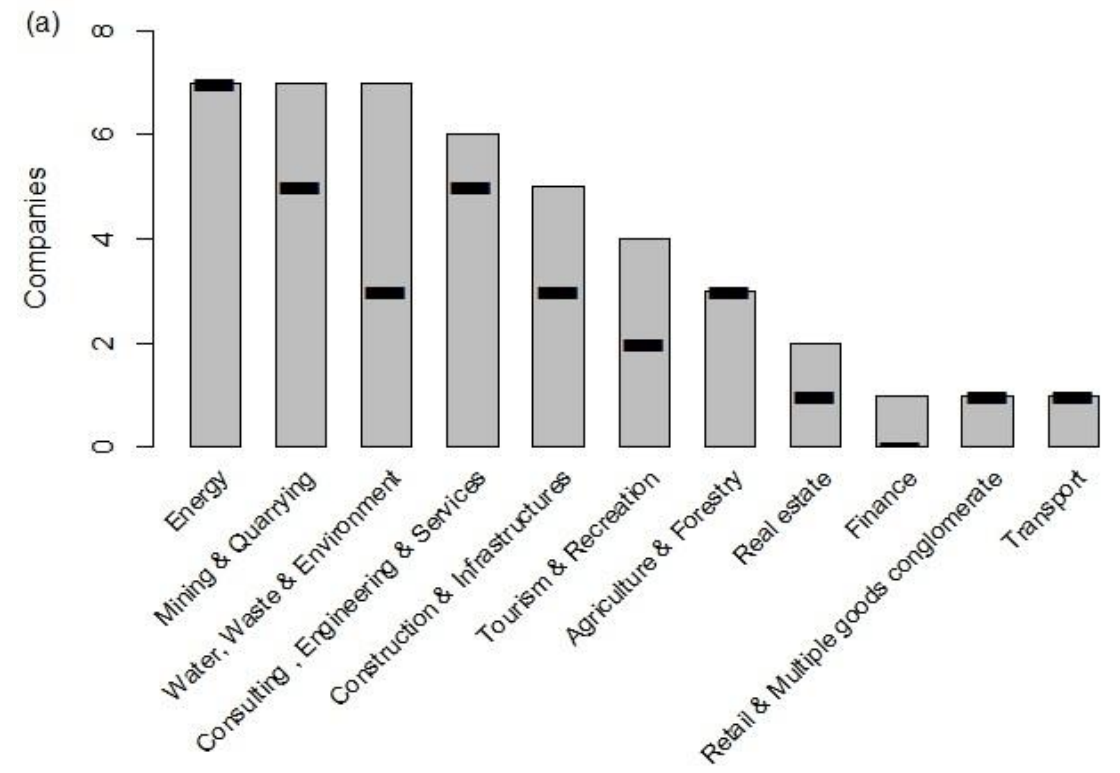

(b)

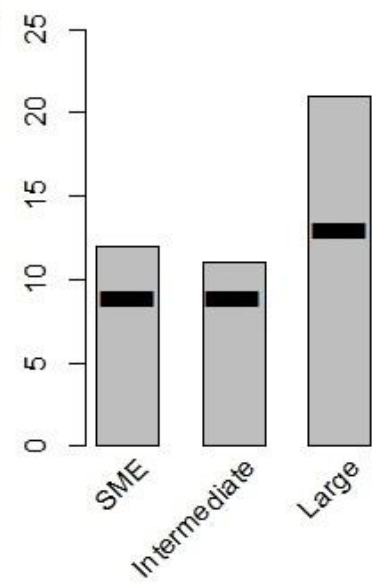

\subsection{Content analysis}

CSR practices and stakeholders' involvement were scrutinized following a content analysis approach:

1. The individual actions that the companies committed to undertake ${ }^{1}$ were identified and extracted from the NBSAP plans.

2. A categorization framework was inductively develop to classify and characterize these actions regarding the types of practices undertaken and the stakeholders involved.

3. Actions were systematically described according to this categorization scheme based on a binary coding. Depending on its complexity and range, a given action could encompass several practices and stakeholders simultaneously.

4. Categories of CSR practices and of stakeholders were interpreted and grouped by themes and action arenas respectively, and the coded data was quantitatively analyzed with the open-source software R studio.

The categorization framework was improved through iterations between steps two to four as new trends emerged from the analysis.

\footnotetext{
${ }^{1}$ Actions were used as unit of analysis to fit the way companies organized their commitment plans. This division showed some limits. Indeed from a company to another, or even in a single plan, scopes of actions showed great variation regarding the financial and human resources needed. We recognize that individual action is an imperfect unit of analysis but it was consistent with how business segmented their initiatives and monitored them. It thus reflects the relative emphasis the companies gave to their initiatives.
} 


\section{Results}

The commitment plans endorsed as contributions to the French NBSAP offered a quite detailed and consistent description of business practices and of the roles played by stakeholders in their implementation. We first present subsequently the typology of CSR practices and the structure of action arenas that emerged from the analysis, and then present findings regarding how these actions arenas are mobilized in the implementation of CSR practices.

\subsection{Corporate practices}

In total, 496 actions that companies committed to undertake were identified. Biodiversityoriented CSR practices were quite heterogeneous across the companies, as they deal differently with biodiversity depending on their sectors, locations, sizes and maturity for instance. Figure 2 displays the typology of practices that emerged from the analysis of these commitment plans. It also provides an overview of the proportion of companies that committed to develop such practices.

Figure 2 - Typology of CSR practices presented in the commitment plans and percentages of companies that committed to undertake them. Activities in bold were presented by more than two-third of the companies.

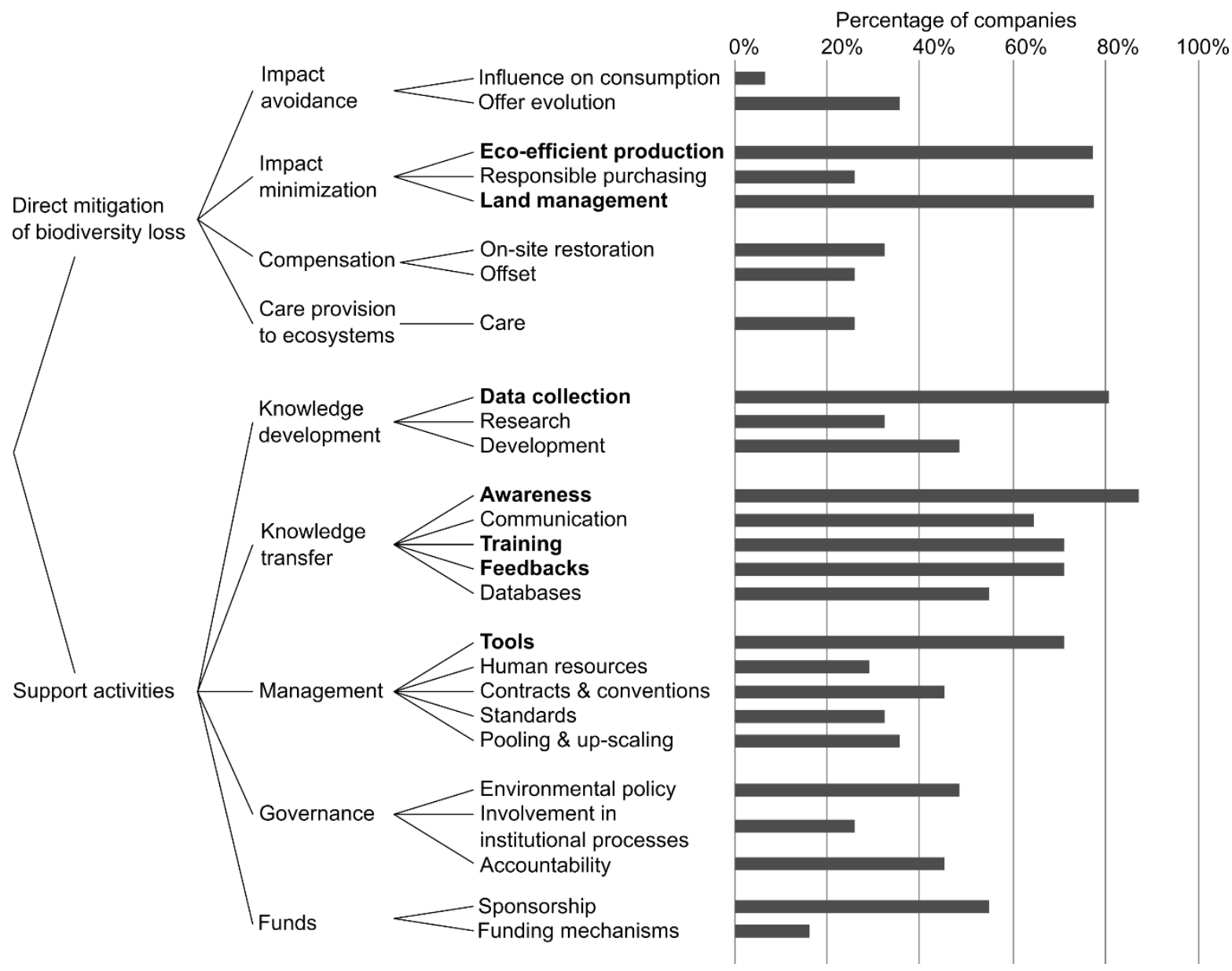

This typology makes a dichotomy between, on one hand, practices that directly mitigate biodiversity loss in an operational way, and on the other hand, procedural activities that support the integration and management of biodiversity issues. 


\subsubsection{Direct mitigation practices}

Direct mitigation practices were classified under: impact avoidance, impact minimization, compensation and care provided to ecosystems. The three first categories are consistent with the three steps of the mitigation hierarchy framework (Cf. Box 2). Avoidance activities, based on the evolution of consumption patterns and of the business portfolio composition, had a preventive character. Minimization practices had a more curative dimension and compensation can be regarded as an end-of-pipe approach. Care activities had an adaptive character as they aimed at increasing the long-term resilience of ecosystems and thus their capacities to support future stresses.

Box 2 - The mitigation hierarchy.

The mitigation hierarchy is a stepwise framework widely used in conservation policy and management. It usually follows three steps: avoid negative impacts whenever possible, then minimize them and eventually compensate/offset the residual impacts in order to achieve no net loss or net positive impact (EU NNL WG, 2013). In France, the mitigation hierarchy was first introduced in the environmental law in 1976, further specified through guidance documents (MEDDE, 2012) and strengthen in 2016 by the law $n^{\circ} 2016-1087$ related to biodiversity. It has been so far mainly applied to projects with substantial land footprint (e.g. mining, infrastructure projects).

It appears that mitigation practices were more or less specifically targeting anthropic pressures. Table 1 summarizes which processes altering biodiversity were addressed in the commitment plans by the active mitigation measures. Habitat loss was addressed by all types of activities while other anthropic pressures were found to be targeted only by avoidance and/or minimization activities.

Table 1 - Anthropic pressures driving biodiversity loss tackled by direct mitigation practices. Pressures explicitly addressed in commitment plans are designated with crosses.

\begin{tabular}{|l|l|c|c|c|c|c|}
\hline Category & Activities & \multicolumn{4}{|c|}{ Pressures responsible for biodiversity loss } \\
\cline { 3 - 7 } & & $\begin{array}{l}\text { Habitat } \\
\text { loss }\end{array}$ & $\begin{array}{l}\text { Pollu- } \\
\text { tions }\end{array}$ & $\begin{array}{l}\text { Invasive } \\
\text { species }\end{array}$ & $\begin{array}{l}\text { Climate } \\
\text { change }\end{array}$ & $\begin{array}{l}\text { Over- } \\
\text { exploitation }\end{array}$ \\
\hline \multirow{2}{*}{$\begin{array}{l}\text { Impact } \\
\text { avoidance }\end{array}$} & $\begin{array}{l}\text { Influence on } \\
\text { consumption }\end{array}$ & $\mathrm{X}$ & $\mathrm{X}$ & & & $\mathrm{X}$ \\
\cline { 2 - 7 } & Offer evolution & $\mathrm{X}$ & $\mathrm{X}$ & & & $\mathrm{X}$ \\
\hline \multirow{2}{*}{$\begin{array}{l}\text { Impact } \\
\text { minimization }\end{array}$} & Eco-efficient production & $\mathrm{X}$ & $\mathrm{X}$ & $\mathrm{X}$ & $\mathrm{X}$ & $\mathrm{X}$ \\
\cline { 2 - 7 } & Responsible purchasing & $\mathrm{X}$ & & & & $\mathrm{X}$ \\
\cline { 2 - 7 } & Land management & $\mathrm{X}$ & $\mathrm{X}$ & $\mathrm{X}$ & & \\
\hline \multirow{2}{*}{ Compensation } & On-site restoration & $\mathrm{X}$ & & & & \\
\cline { 2 - 7 } & Offset & $\mathrm{X}$ & & & & \\
\hline Care provision to ecosystems & $\mathrm{X}$ & & & & \\
\hline
\end{tabular}

The most recurrent mitigation initiatives were two minimization measures: eco-efficient production and land management (Figure 2). Land management measures aimed generally at moving from 'conventional' green space management to more ecologically sound practices. For instance, one company proposed "to phase out pesticides, to ban invasive plants, to substitute horticultural varieties by local plants, to delay and limit the number of mowing" (Eiffage, 2015, p. 30). The area effectively covered by such land management practices and their consistency at a landscape scale were found to greatly differ among companies. Eco- 
efficient production initiatives were more closely related to core business activities. Some practices aimed for instance at limiting invasive species diffusion by improving excavated soil management, at reducing dams' fragmentation of freshwater habitats or at decreasing light pollution of industrial sites overnight. Eco-efficient production practices encompassed thus a variety of technical measures reducing the industrial impacts on biodiversity. They addressed in various ways the all range of anthropic pressures (Table 1).

\subsubsection{Support activities}

A relatively strong emphasis was put in the commitment plans on support activities (Figure 2). These were classified into categories related to knowledge development and knowledge diffusion, development of managerial capacities, governance and funding of biodiversity conservation.

Among support activities, the most frequent practices (implemented by more than two thirds of the companies) were related to: ecological data collection, tools development, raising awareness, providing training and sharing feedbacks. Data collection - sometimes part of larger programs led by an NGO or a scientific institution - included fauna and flora inventories, but also ecosystems mapping, geochemical soil analyses, monitoring of invasive species... Contribution to voluntary fauna and flora inventories was especially developed in sectors that are subject to environmental impact assessments on a regulatory basis (e.g. mining and quarrying). To track the improvement of their ecological performance, companies put also efforts in tools development, enabling the integration of biodiversity components in their internal environmental management system, or producing metrics and indicators for assessing business impacts.

A gradient of technicity was observed among the knowledge transfer practices. Awareness raising had the broader scope and targeted a non-specialist audience (public, employees, clients, partners...). While campaigns often addressed biodiversity issues in general (e.g. the importance of biodiversity and its decline), they were sometimes tailored more specifically to the company (e.g. business-biodiversity interactions, species present onsite). The distinction between awareness and communication practices was thin, as the media used to increase awareness about biodiversity were usually simultaneously used to promote the company's good practices. Training activities were more centered on the issues encountered by the company itself and were dedicated both to the operational staff (how to implement recommendations in day-to-day practices) and to managers (how to integrate biodiversity issues into decisionmaking processes). Finally, feedbacks aimed at disseminating results of experimental approaches and at upscaling best practices through internal or sectoral publications and working groups. For instance, several committed companies contributed as members of the 'Linear infrastructure and Biodiversity Club' to the publication of a report providing recommendations for "optimising the connection between ecological networks and infrastructure networks" (e.g. roads, gas pipelines, electric power lines) (IUCN France and CILB, 2015, p. 14).

While not tackling directly the processes responsible for biodiversity loss, support activities contributed to institutionalize biodiversity issues in companies at different levels. 


\subsection{Action arenas}

The implementation of these biodiversity-oriented CSR practices relied on multiple stakeholders. These stakeholders were grouped into four action arenas (Figure 3):

- within companies, where environment managers played a central role to coordinate and structure the actions. This action arena also included the top management and staff members ranging from operators to $\mathrm{R} \& \mathrm{D}$ and marketing managers;

- territorial systems where the company operates. The territorial stakeholders were local communities, councils with political influence on the territory (e.g. municipalities, local officials) and experts with specific naturalist knowledge on the local ecosystems;

- the value chain of the company, encompassing suppliers, clients and project-specific economic partners;

- and finally, the institutional system that set the regulations, taxes, norms and biodiversity policies. The stakeholders grouped in this action arena had influence capacities at a national level or broader: public institutions playing an administrative or political role, large environmental NGOs, academic institutions and professional organizations.

Figure 3 - Action arenas and stakeholders involved.

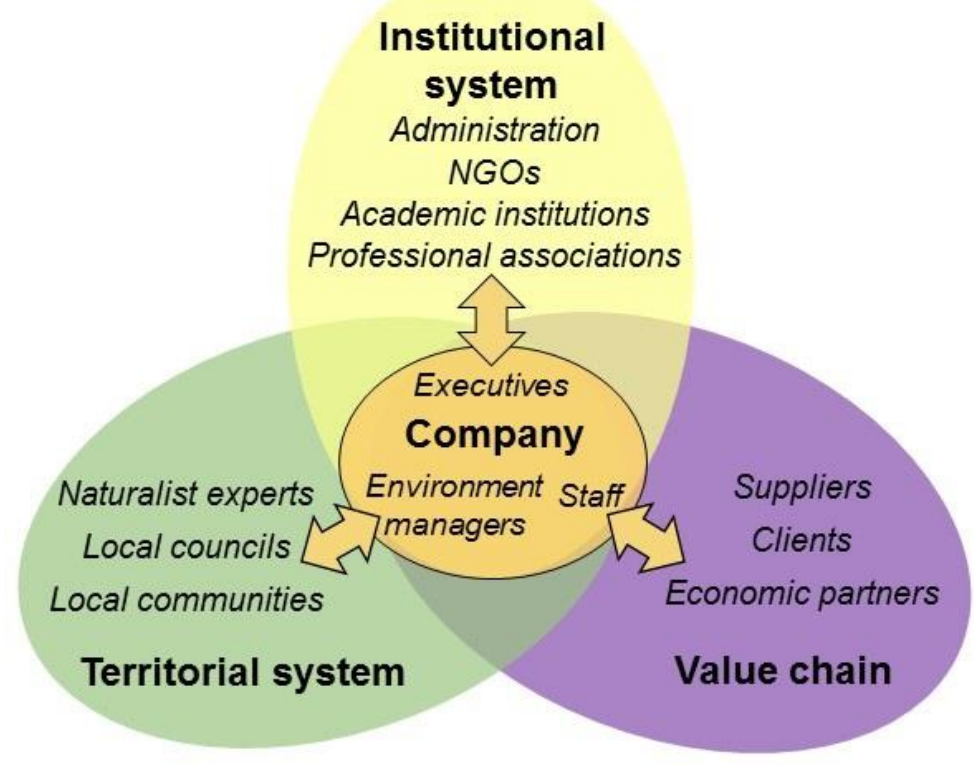

Although classified under a unique action arena, some stakeholders could be regarded as acting at the interface. This was notably the case of local councils that made the connection between the institutional and the territorial systems, as well as industrial organizations that made the link between value chains and the institutional system. In some cases, the company's value chain was embedded into the territorial system. This situation was notably encountered within small companies with local suppliers and clients. Thus, the apparent overlap between these four action arenas in the commitment plans was highly dependent on the companies' characteristics: business size, sector, number of industrial sites... 
External stakeholders were found to be involved in $70 \%$ of the actions presented in the commitment plans, suggesting they played key roles in the implementation of biodiversityoriented CSR. Globally, each company apparently interacted with a diversity of external stakeholders. Most systematically involved stakeholders were large NGOs and local councils (both cited in $77 \%$ of the commitment plans) as well as naturalist experts with local knowledge (cited in $74 \%$ of the commitment plans). The analysis suggested some sectoral differences. The companies belonging to the energy, mining \& quarrying and waste-water-environment sectors seemed to have quite intense interactions with territorial stakeholders. For instance, the quarry company STB Matériaux emphasized its interactions with local land-management agencies to optimize post-exploitation restoration projects. GRTgaz, that manages pipeline networks, stated that its collaborations "with local actors has helped define pipeline delineation respectful of the territory" and that "the informed advice of local partners contributed to propose avoidance and compensation measures going often beyond regulatory requirements" (GRTgaz, 2013, p. 13). In contrast, construction \& infrastructure companies appeared to be more largely involved with institutional stakeholders. Eiffage for example made a specific focus on its participation to diverse working groups and colleges led by public institutions, foundations, associations and industrial coalitions.

\subsection{Stakeholders' roles in biodiversity-oriented CSR activities}

Stakeholders were involved either as executors, supporters or targets of the biodiversityoriented measures. Stakeholders belonging to the value chain, the territorial system and the institutional system were respectively involved in $25 \%, 34 \%$ and $38 \%$ of the actions presented in the commitment plans. The analysis of their involvement in the different kind of activities suggests that these three action arenas played distinct roles (Table 1).

The value chain appeared to be quite frequently mobilized in the implementation of direct mitigation practices. The roles of the value chain stakeholders were polarized by their upstream (suppliers) or downstream (clients) positions in the value chain. Actions involving the downstream side of the value chain had been primarily qualified as avoidance measures. To address clients, companies adopted two complementary approaches:

- a demand-side approach, to influence clients' expectations and needs toward more ecologically sound consumption patterns,

- and an offer-side approach by developing new low-impact portfolios of products and services.

In contrast, CSR practices mobilizing the upstream side of the value chain were mainly minimization measures. Suppliers acted as both targets and executors of minimization activities, as some companies encouraged or requested them to comply with specific guidelines and ecological standards.

Stakeholders from the territorial system were apparently mobilized by companies in heterogeneous ways. Territorial councils were found to be involved in almost all kind of probiodiversity activities. Naturalist experts were more specialized in data collection (e.g. fauna and flora inventories) and improvement of land management as they notably provided recommendations to companies to better integrate their activities in the local ecosystems. The general public and local communities were essentially the targets of events and communication program aiming at raising awareness and promoting the actions taken by the companies. 
Finally, the stakeholders from the institutional system, which were the most represented categories of actors in the NBSAP evaluation committee (Cf. Section 3.1), were also the most frequently cited in the commitment plans. The institutional stakeholders were essentially mobilized in support activities. The primary role of professional organizations was related to disseminating feedbacks. Environmental NGOs were the principal beneficiaries of business sponsorship, but also played a supporting role in raising awareness, developing trainings and sharing experiences and best practices among actors. Academics were found to be specifically involved in ecological knowledge development as well as in knowledge transfer through the development of databases and were also substantial beneficiaries of sponsorship. The administration was the less cited stakeholder category in activities implementation, with no clear pattern of involvement.

Table 1 - Action arenas mobilized for the activities: percentage of actions for which stakeholders belonging to the value chain, the territorial system or the institutional system are involved (most solicited action arena is highlighted in grey).

\begin{tabular}{|c|c|c|c|c|c|}
\hline \multicolumn{2}{|c|}{ Categories } & $\begin{array}{l}\text { Activities } \\
(\mathrm{n}=\text { action count })\end{array}$ & $\begin{array}{l}\text { Value } \\
\text { chain }\end{array}$ & $\begin{array}{l}\text { Territorial } \\
\text { system }\end{array}$ & $\begin{array}{l}\text { Institutional } \\
\text { system }\end{array}$ \\
\hline \multirow{8}{*}{ 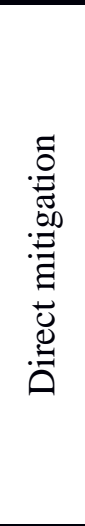 } & \multirow[t]{2}{*}{ Impact avoidance } & $\begin{array}{l}\text { Influence on consumption } \\
(\mathrm{n}=2)\end{array}$ & $100 \%$ & $50 \%$ & $50 \%$ \\
\hline & & Offer evolution $(\mathrm{n}=27)$ & $89 \%$ & $22 \%$ & $37 \%$ \\
\hline & \multirow{3}{*}{$\begin{array}{l}\text { Impact } \\
\text { minimization }\end{array}$} & $\begin{array}{l}\text { Eco-efficient production } \\
(\mathrm{n}=69)\end{array}$ & $45 \%$ & $30 \%$ & $28 \%$ \\
\hline & & Responsible purchasing $(\mathrm{n}=18)$ & $89 \%$ & $6 \%$ & $11 \%$ \\
\hline & & Land management $(n=123)$ & $31 \%$ & $37 \%$ & $29 \%$ \\
\hline & \multirow{2}{*}{ Compensation } & On-site restoration $(\mathrm{n}=24)$ & $25 \%$ & $75 \%$ & $46 \%$ \\
\hline & & Offset $(n=11)$ & $82 \%$ & $45 \%$ & $45 \%$ \\
\hline & $\begin{array}{l}\text { Care provision to } \\
\text { ecosystems }\end{array}$ & Care $(n=9)$ & $56 \%$ & $56 \%$ & $44 \%$ \\
\hline \multirow{18}{*}{ 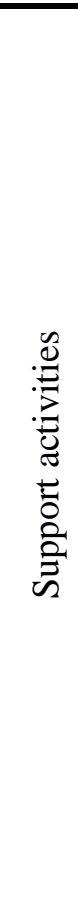 } & \multirow{3}{*}{$\begin{array}{l}\text { Knowledge } \\
\text { development }\end{array}$} & Data collection $(n=74)$ & $23 \%$ & $58 \%$ & $57 \%$ \\
\hline & & Research $(\mathrm{n}=29)$ & $10 \%$ & $28 \%$ & $93 \%$ \\
\hline & & Development $(\mathrm{n}=53)$ & $40 \%$ & $28 \%$ & $53 \%$ \\
\hline & \multirow{5}{*}{$\begin{array}{l}\text { Knowledge } \\
\text { transfer }\end{array}$} & Awareness $(n=138)$ & $30 \%$ & $42 \%$ & $33 \%$ \\
\hline & & Communication $(n=45)$ & $22 \%$ & $47 \%$ & $31 \%$ \\
\hline & & Training $(\mathrm{n}=46)$ & $33 \%$ & $35 \%$ & $48 \%$ \\
\hline & & Feedbacks $(n=67)$ & $30 \%$ & $34 \%$ & $45 \%$ \\
\hline & & Databases $(n=28)$ & $14 \%$ & $50 \%$ & $75 \%$ \\
\hline & \multirow{5}{*}{ Management } & Tools $(n=48)$ & $25 \%$ & $21 \%$ & $40 \%$ \\
\hline & & Human resources $(n=9)$ & $44 \%$ & $22 \%$ & $22 \%$ \\
\hline & & $\begin{array}{l}\text { Contracts \& conventions } \\
(\mathrm{n}=32)\end{array}$ & $44 \%$ & $50 \%$ & $38 \%$ \\
\hline & & Standards $(n=12)$ & $25 \%$ & $25 \%$ & $42 \%$ \\
\hline & & Pooling \& up-scaling $(\mathrm{n}=16)$ & $63 \%$ & $31 \%$ & $44 \%$ \\
\hline & \multirow{3}{*}{ Governance } & Environmental policy $(\mathrm{n}=21)$ & $43 \%$ & $33 \%$ & $24 \%$ \\
\hline & & $\begin{array}{l}\text { Involvement in institutional } \\
\text { processes }(n=22)\end{array}$ & $18 \%$ & $59 \%$ & $68 \%$ \\
\hline & & Accountability $(n=15)$ & $47 \%$ & $33 \%$ & $33 \%$ \\
\hline & \multirow{2}{*}{ Funds } & Sponsorship $(n=39)$ & $8 \%$ & $46 \%$ & $79 \%$ \\
\hline & & Funding mechanisms $(n=8)$ & $88 \%$ & $38 \%$ & $25 \%$ \\
\hline
\end{tabular}




\section{Discussion and conclusions}

This research provides a detailed and trans-industry typology of biodiversity-oriented CSR practices that were implemented by companies as contributions to the French NBSAP. We suggest that this structured classification could be used to design research protocols on corporate biodiversity management in a consistent manner and facilitate inter-sectoral comparisons. It complements the framework proposed by Boiral and Heras-Saizarbitoria that classified biodiversity management practices based on their technical vs. managerial character and on their internal vs. external implementation (Boiral and Heras-Saizarbitoria, 2017a). While the framework of Boiral and Heras-Saizarbitoria focuses on organizational aspects, the typology proposed in this paper takes a more biodiversity-centered view as it discriminates on one hand activities that directly mitigate biodiversity loss (impact avoidance, minimization and compensation, as well as care provision) and on the other hand, procedural activities that provide support for a better integration of biodiversity issues (through knowledge generation and diffusion, development of management capacities, governance and funding). This diversity of actions should be fully exploited and synergies explored by researchers and practitioners. This typology could be an operational benchmark tool for managers to identify the strengths and weaknesses of the biodiversity action plans of their own organizations. Two types of imbalance between business practices were observed in the present study. First, support activities dominated in the commitment plans. A strong focus on support activities at the expense of direct mitigation practices poses the risk to undermine the actual contribution of businesses to biodiversity conservation. Second, direct mitigation practices were primarily minimization of impacts. This finding is consistent with the results of other studies that show that the mitigation hierarchy is often biased by economic actors who tend in practice to downplay the first avoidance step and focus primarily on impacts minimization (Bigard et al., 2017; Phalan et al., 2017). It thus seems critical to reduce such imbalances to enhance the effective contribution of CSR to biodiversity conservation.

This case study also gives insights regarding the action arenas that support the implementation of such activities through the involvement of different stakeholder groups. Companies were found to extensively interact with stakeholders, highlighting the collaborative nature of biodiversity-oriented CSR practices. Our results thus comfort the idea that stakeholders are used as a positive lever by companies to manage biodiversity issues (Boiral and Heras-Saizarbitoria, 2017b; Overbeek et al., 2013). Furthermore, the analysis suggests that stakeholders from the territorial system, the value chain and the institutional system are involved at various degrees in the different categories of CSR practices. So business strategies should be designed by taking into account stakeholders' complementarities. More specifically, our results suggest that value chains play a central role in the implementation practices that directly mitigate biodiversity loss. Previous studies have pointed out that companies encounter inherent management difficulties in this action arena whose scope can be very broad (Fritz et al., 2018; Kogg and Mont, 2012). We thus suggest that future research could help identify more precisely how a company may interact with the various stakeholders along its supply chain and the impacts of such interactions on environmental pressures mitigation.

Although the scope of the corporate commitments to the French NBSAP is quite specific, the lessons from this case study may be relevant at a broader scale, notably for other companies and in other countries. The companies whose commitment plans have been analyzed represent a large variety of sectors and business sizes. They cannot be considered as representative of the 
private sector as a whole as they clearly displayed proactive behavior in biodiversity conservation through their engagement in the NBSAP mechanism. Somehow, with the exception of a few small companies, it can be noticed that most of these companies have primarily 'conventional' business models (in contrast with 'niche' sustainable companies, whose business models would be imbedded in ecological entrepreneurship). They exhibited a global dynamic that could be characterized as continuous improvement, a frequent approach in companies that are concerned by CSR and environmental management. Furthermore, while our research is based on a French case study, some of our results may also be relevant in other places, notably in developed countries with a comparable level of environmental regulation, for instance other European Union member states. We found for instance a significant overlap between the typology of CSR practices that came out of this analysis and categories of business practices identified in Netherlands (Overbeek et al., 2013) and Germany (Schaltegger and Beständig, 2012). The applicability of these findings in other contexts is less obvious as the institutional and political environment greatly influence CSR and interactions with stakeholders (Doh and Guay, 2006). We thus suggest that the robustness and possible extrapolations of these results should be further explored through case study research notably by (i) testing the relevance of the CSR practices typology for specific industries, (ii) examining if action arenas are mobilized in a similar way by companies operating in developing countries, and (iii) analyzing the outcomes of other voluntary approaches (e.g. voluntary industry initiatives) compared to programs driven by public authorities.

While recognizing that further research is needed to comfort the representativeness of our findings, we draw some recommendations for future policy developments on how to integrate CSR activities within conservation policies. More precisely, we discuss here how CSR could be better connected to two important policy tools: the mitigation hierarchy and NBSAPs.

The mitigation hierarchy has been primarily developed for projects with a substantial land footprint - e.g. infrastructure construction projects, carries - to achieve no net loss of natural habitat. This study highlights that CSR activities that fit into the structure of the mitigation hierarchy are already implemented by a larger diversity of sectors, though not always conceptualized this way, and that they can address not only habitat degradation but also other anthropic pressures. We thus argue for an extension of this framework to systematically address the ecological pressures exerted across sectors. Such extensions have already been partially explored for instance for the commercial agriculture and forestry sectors (Aiama et al., 2015) and to integrate climate change issues in forests compensation (Sansilvestri et al., 2015). Furthermore, adding a 'care' step would make this framework practicable for the companies working in ecological engineering.

NBSAPs, which are the main instruments to implement the CBD at a national level, will be renewed in about two years. Sarkki et al. foresaw that "there is space in the national policy systems for NBSAP processes especially to facilitate iterative multi-sector dialogue, to support innovations for combining business and biodiversity and to develop institutional responsibilities, as well as a sense of commitment towards biodiversity" (Sarkki et al., 2016, p. 17). To adopt a more strategic approach in mobilizing business in NBSAPs, policy makers may translate national targets into explicit sectoral objectives in order to set expectations regarding business contributions (Wolff, 2017). The typology developed in this paper may provide policymakers with a support to consistently review business commitments, and identify potential gaps and imbalances. Finally, given the role stakeholders appear to play, it may be relevant to design 
policy tools that address companies not as individual actors but rather as organizations that can extend their scope of action beyond their own perimeter through their value chains, their geographic locations and their institutional networks.

\section{Acknowledgments}

The authors would like to thank the companies that accepted to give them access to their commitment plans.

Funding: This work was supported by AgroParistech and Mines Saint-Etienne.

\section{$\underline{\text { Vitae }}$}

Anastasia Wolff has a $\mathrm{PhD}$ degree in environmental sciences. She studies the potential of corporate social responsibility (CSR) to contribute to biodiversity conservation.

Natacha Gondran is associate professor in environmental assessment at Mines Saint-Etienne and affiliated to the interdisciplinary laboratory 'Environment, city and society' (UMR 5600).

Christian Brodhag is Professor at Mines Saint-Etienne. He works on sustainable development, social responsibility and innovation. He had also administrative and political experience in sustainable development.

\section{Bibliography}

Adler, R., Mansi, M., Pandey, R., Stringer, C., 2017. United Nations Decade on Biodiversity: A study of the reporting practices of the Australian mining industry. Acc Auditing Accountability J 30, 1711-1745. doi:10.1108/AAAJ-04-2015-2028

Aiama, D., Edwards, S., Bos, G., Ekstrom, J., Krueger, L., Quétier, F., Savy, C., Semroc, B., Sneary, M., Bennun, L., 2015. No Net Loss and Net Positive Impact Approaches for Biodiversity - Exploring the potential application of these approaches in the commercial agriculture and forestry sectors. IUCN, Gland, Switzerland.

Barkemeyer, R., Stringer, L.C., Hollins, J.A., Josephi, F., 2015. Corporate reporting on solutions to wicked problems: Sustainable land management in the mining sector. Environmental Science \& Policy 48, 196-209. doi:10.1016/j.envsci.2014.12.021

Bigard, C., Pioch, S., Thompson, J.D., 2017. The inclusion of biodiversity in environmental impact assessment: Policy-related progress limited by gaps and semantic confusion. Journal of Environmental Management 200, 35-45. doi:10.1016/j.jenvman.2017.05.057

Boiral, O., Heras-Saizarbitoria, I., 2017a. Best practices for corporate commitment to biodiversity: An organizing framework from GRI reports. Environmental Science \& Policy 77, 77-85. doi:10.1016/j.envsci.2017.07.012

Boiral, O., Heras-Saizarbitoria, I., 2017b. Managing Biodiversity Through Stakeholder Involvement: Why, Who, and for What Initiatives? J Bus Ethics 140, 403-421. doi:10.1007/s10551-015-2668-3

Bonini, S., Oppenheim, J.M., 2010. The next environmental issue for business: McKinsey Global Survey results. McKinsey \& Company.

Börkey, P., Glachant, M., Lévêque, F., 2000. Voluntary Approaches for Environmental Policy. An assessment. Organisation for Economic Co-operation and Development, Paris. 
CBD, online. Case Studies on Business and Biodiversity. https://www.cbd.int/business/ressources/case-studies.shtml

Ceballos, G., Ehrlich, P.R., Dirzo, R., 2017. Biological annihilation via the ongoing sixth mass extinction signaled by vertebrate population losses and declines. PNAS 201704949. doi:10.1073/pnas.1704949114

COP10 CBD, 2010. Decision X/21. Business engagement. Convention pour la diversité biologique, Nagoya, Japan.

Delmas, M.A., Etzion, D., Nairn-Birch, N., 2013. Triangulating environmental performance: What do corporate social responsibility ratings really capture? The Academy of Management Perspectives 27, 255-267.

de Snoo, G.R., Herzon, I., Staats, H., Burton, R.J.F., Schindler, S., van Dijk, J., Lokhorst, A.M., Bullock, J.M., Lobley, M., Wrbka, T., Schwarz, G., Musters, C. j. m., 2013. Toward effective nature conservation on farmland: making farmers matter. Conservation Letters 6, 66-72. doi:10.1111/j.1755-263X.2012.00296.x

DiMaggio, P.J., Powell, W.W., 1983. The Iron Cage Revisited: Institutional Isomorphism and Collective Rationality in Organizational Fields. American Sociological Review 48, 147-160. doi:10.2307/2095101

Doda, B., Gennaoli, C., Gouldson, A., Grover, D., Sullivan, R., 2016. Are Corporate Carbon Management Practices Reducing Corporate Carbon Emissions? Corporate Social Responsibility and Environmental Management 23, 257-270.

Doh, J.P., Guay, T.R., 2006. Corporate Social Responsibility, Public Policy, and NGO Activism in Europe and the United States: An Institutional-Stakeholder Perspective. Journal of Management Studies 43, 47-73.

Doremus, H., 2003. A policy portfolio approach to biodiversity protection on private lands. Environmental Science \& Policy, Protecting Nature on Private Land - From Conflicts to Agreements 6, 217-232. doi:10.1016/S1462-9011(03)00036-4

Eiffage, 2015. Programme d'actions d'Eiffage 2015-2018 au titre du renouvellement de son engagement dans la Stratégie Nationale pour la Biodiversité. http://www.developpementdurable.eiffage.com/uploads/2016/Env/programme\%20dac tions\%20SNB\%20Eiffage\%202015-2018.pdf

Ernst, E., Honoré-Rougé, Y., 2012. La responsabilité sociétale des entreprises : une démarche déjà répandue. Insee Première.

EU NNL WG, 2013. No Net Loss Glossary. EU No Net Loss Working Group.

European Commission, 2011. A renewed EU strategy 2011-14 for Corporate Social Responsibility.

Feger, C., 2016. Nouvelles comptabilités au service des écosystèmes. Une recherche engagée auprès d'une entreprise du secteur de l'environnement. AgroParisTech, Paris, France.

Fritz, M.M.C., Rauter, R., Baumgartner, R.J., Dentchev, N., 2018. A supply chain perspective of stakeholder identification as a tool for responsible policy and decision-making. Environmental Science \& Policy 81, 63-76. doi:10.1016/j.envsci.2017.12.011

Green, A.O., Hunton-Clarke, L., 2003. A typology of stakeholder participation for company environmental decision-making. Bus. Strat. Env. 12, 292-299. doi:10.1002/bse.371

GRTgaz, 2013. Engagement volontaire de GRTgaz en faveur de la Biodiversité. http://www.grtgaz.com/fileadmin/medias/communiques/2014/fr/strategie-nationalebiodiversite-plan-dengagement.pdf

Houdet, J., Trommetter, M., Weber, J., 2012. Understanding changes in business strategies regarding biodiversity and ecosystem services. Ecological Economics 73, 37-46. doi:10.1016/j.ecolecon.2011.10.013

IFC, 2012. Performance Standard 6. Biodiversity Conservation and Sustainable Management of Living Natural Resources. International Finance Corporation, World Bank Group. 
ISO, 2010. ISO 26000:2010. Guidance on social responsibility. ISO, Geneva.

IUCN France, CILB, 2015. Infrastructure corridors, ecological corridors? Status report and recommendations. IUCN France, Club des infrastructures linéaires et Biodiversité.

King, A.A., Lenox, M.J., 2000. Industry Self-Regulation Without Sanctions: The Chemical Industry's Responsible Care Program. Academy of Management Journal 43, 698-716. doi: $10.2307 / 1556362$

Kogg, B., Mont, O., 2012. Environmental and social responsibility in supply chains: The practise of choice and inter-organisational management. Ecological Economics, Sustainability in Global Product Chains 83, 154-163. doi:10.1016/j.ecolecon.2011.08.023

Lambooy, T., Levashova, Y., 2011. Opportunities and challenges for private sector entrepreneurship and investment in biodiversity, ecosystem services and nature conservation. International Journal of Biodiversity Science, Ecosystem Services \& Management 7, 301-318. doi:10.1080/21513732.2011.629632

Lavoux, T., Neveu, A., 2015. Dispositif de mise en oeuvre de la Stratégie nationale pour la biodiversité 2011-2020. Constats et propositions de relance (No. 010203-01). Conseil général de l'environnement et du développement durable, Paris, France.

Lyon, T.P., Maxwell, J.W., 2008. Corporate Social Responsibility and the Environment: A Theoretical Perspective. Review of Environmental Economics and Policy 2, 240-260. doi:10.1093/reep/ren004

MacDonald, K.I., 2010. The Devil is in the (Bio)diversity: Private Sector "Engagement" and the Restructuring of Biodiversity Conservation. Antipode 42, 513-550. doi:10.1111/j.1467-8330.2010.00762.x

MEDDE, 2012. Doctrine relative à la séquence éviter, réduire et compenser les impacts sur le milieu naturel. Ministère de l'Écologie, du Développement Durable et de l'Energie, Paris, France.

Millennium Ecosystem Assessment, 2005. Ecosystems and Human Well-Being: Current State and Trends, Island Press. ed. Washington, D.C., USA.

Ministère de la transition écologique et solidaire, 2017. Stratégie nationale pour la biodiversité. http://www.developpement-durable.gouv.fr/strategie-nationale-biodiversite

Morgera, E., 2012. From Corporate Social Responsibility to Accountability Mechanisms: The Role of the Convention on Biological Diversity (SSRN Scholarly Paper No. ID 1995521). Social Science Research Network, Rochester, NY.

OECD, 2011. OECD Guidelines for Multinational Enterprises. OECD Publishing.

Ostrom, E., 2010. Institutional Analysis and Development: Elements of The Framework in Historical Perspective, in: Crothers, C. (Ed.), Historical Developments and Theoretical Approaches in Sociology - Volume II. EOLSS Publications, pp. 261-288.

Overbeek, G., Harms, B., 2011. From sponsor to partner: NGO-business alliances that support nature conservation in the Netherlands. Journal of Integrative Environmental Sciences 8, 253-266. doi:10.1080/1943815X.2011.608071

Overbeek, G., Harms, B., Van Den Burg, S., 2013. Biodiversity and the Corporate Social Responsibility Agenda. Journal of Sustainable Development 6. doi:10.5539/jsd.v6n9p1

Phalan, B., Hayes, G., Brooks, S., Marsh, D., Howard, P., Costelloe, B., Vira, B., Kowalska, A., Whitaker, S., 2017. Avoiding impacts on biodiversity through strengthening the first stage of the mitigation hierarchy. Oryx 1-9. doi:10.1017/S0030605316001034

Pirard, R., 2012. Market-based instruments for biodiversity and ecosystem services: A lexicon. Environmental Science \& Policy 19-20, 59-68. doi:10.1016/j.envsci.2012.02.001

Prime Minister, 2011. National Biodiversity Strategy 2011-2020. french Prime Minister, Paris, France. 
Reade, C., Goka, K., Thorp, R., Mitsuhata, M., Wasbauer, M., 2014. CSR, Biodiversity and Japan's Stakeholder Approach to the Global Bumble Bee Trade. The Journal of Corporate Citizenship 54-66.

Robinson, J.G., 2012. Common and Conflicting Interests in the Engagements between Conservation Organizations and Corporations. Conservation Biology 26, 967-977. doi:10.1111/j.1523-1739.2012.01914.x

Rose, M., Colchester, M., 2004. Green Corporate partnerships - are they an essential tool in achieving the conservationist mission, or just a ruse for covering up ecological crimes?

Sampford, C., 2002. Environmental governance for biodiversity. Environmental Science \& Policy 5, 79-90. doi:10.1016/S1462-9011(02)00027-8

Sansilvestri, R., Roturier, S., Colas, B., Fernandez-Manjarrés, J., Frascaria-Lacoste, N., 2015. Intégrer le facteur climatique dans la compensation écologique. L'exemple des écosystèmes forestiers, in: Restaurer La Nature Pour Atténuer Les Impacts Du Développement, Synthèses. Levrel, Frascaria-Lacoste, Hay, Martin Pioch, Paris, France, pp. 182-190.

Santangeli, A., Arroyo, B., Dicks, L.V., Herzon, I., Kukkala, A.S., Sutherland, W.J., Moilanen, A., 2016. Voluntary non-monetary approaches for implementing conservation. Biological Conservation 197, 209-214. doi:10.1016/j.biocon.2016.03.013

Sarkki, S., Niemelä, J., Tinch, R., Jäppinen, J.-P., Nummelin, M., Toivonen, H., Weissenberg, M.V., 2016. Are national biodiversity strategies and action plans appropriate for building responsibilities for mainstreaming biodiversity across policy sectors? The case of Finland. Journal of Environmental Planning and Management 59, 1377-1396. doi:10.1080/09640568.2015.1076384

SCBD, 2010. Global Biodiversity Outlook 3. Secretariat of the Convention on Biological Diversity (SCBD), Montreal, Canada.

Schaltegger, S., Beständig, U., 2012. Corporate Biodiversity Management Handbook. Biodiversity in Good Company.

Secretariat of the Convention on Biological Diversity, 2011. NBSAP training modules version 2.1 - Module 3. Mainstreaming biodiversity into national sectoral and cross-sectoral strategies, policies, plans and programs. Montreal, Canada.

STB Matériaux, 2013. Engagement http://www.stbmateriaux.fr/images/pdf/engagements_snb.pdf

Steurer, R., 2010. The role of governments in corporate social responsibility: characterising public policies on CSR in Europe. Policy Sci 43, 49-72. doi:10.1007/s11077-009-90844

Sutherland, W.J., Adams, W.M., Aronson, R.B., Aveling, R., Blackburn, T.M., Broad, S., Ceballos, G., Côté, I.M., Cowling, R.M., Da Fonseca, G. a. B., Dinerstein, E., Ferraro, P.J., Fleishman, E., Gascon, C., HUNTER Jr., M., Hutton, J., Kareiva, P., Kuria, A., Macdonald, D.W., Mackinnon, K., Madgwick, F.J., Mascia, M.B., Mcneely, J., MilnerGulland, E.J., Moon, S., Morley, C.G., Nelson, S., Osborn, D., Pai, M., Parsons, E.C.M., Peck, L.S., Possingham, H., Prior, S.V., Pullin, A.S., Rands, M.R.W., Ranganathan, J., Redford, K.H., Rodriguez, J.P., Seymour, F., Sobel, J., Sodhi, N.S., Stott, A., VanceBorland, K., Watkinson, A.R., 2009. One Hundred Questions of Importance to the Conservation of Global Biological Diversity. Conservation Biology 23, 557-567. doi:10.1111/j.1523-1739.2009.01212.x

TEEB, 2012. The Economics of Ecosystems and Biodiversity in Business and Enterprise. Joshua Bishop, Earthscan, London and New York.

TIGF, 2013. Dossier d'engagement de TIGF à la Stratégie nationale pour la biodiversité 20112020 . 
https://www.tigf.fr/fileadmin/Nos_publications/Publications_institutionnelles/2016/En gagement_TIGF_SNB_vFINALE_nouveau_logo2.pdf

Vertdéco, 2013. Notre engagement volontaire pour la stratégie nationale pour la biodiversité. http://www.vertdeco.fr/wp-content/uploads/2014/01/Dossier-dengagement-volontaireSNB.pdf

Winn, M.I., Pogutz, S., 2013. Business, Ecosystems, and Biodiversity New Horizons for Management Research. Organization Environment 26, 203-229. doi:10.1177/1086026613490173

Wolff, A., 2017. Responsabilité sociétale: quelles contributions des entreprises à la conservation de la biodiversité ? (PhD thesis). Université de Lyon; Ecole des mines de Saint Etienne, Saint-Étienne, France.

Wolff, A., Gondran, N., Brodhag, C., 2017a. Les outils d'évaluation de la biodiversité et des services écosystémiques recommandés aux entreprises : compromis entre crédibilité, pertinence et légitimité. Développement durable et territoires. doi:10.4000/developpementdurable.11649

Wolff, A., Gondran, N., Brodhag, C., 2017b. Detecting unsustainable pressures exerted on biodiversity by a company. Application to the food portfolio of a retailer. Journal of Cleaner Production 166, 784-797. doi:10.1016/j.jclepro.2017.08.057

Wolff, F., Schmitt, K., 2009. In hunt for sustainable seafood: sustainaibility effects of CSR in three fish processing companies, in: Corporate Social Responsibility in Europe: Rhetoric and Realities. Edward Elgar Publishing, pp. 157-189. 